\title{
EXPERIMENTAL INVESTIGATION OF PHOTOVOLTAIC PERFORMANCE OF SILICON SOLAR CELL BY USING COPPER DOPED TIO $_{2}$ THIN FILM
}

\author{
CH. CHAITANYA ${ }^{1}$, SANDEEP YECHURI ${ }^{2} \&$ K. RAMAKRISHNA ${ }^{3}$ \\ ${ }^{1}$ Student, Department of Mechanical Engineering, Koneru Lakshmaiah Education Foundation, \\ Vaddeswaram, Guntur, Andhra Pradesh, India \\ ${ }^{2}$ Assistant Professor, Department of Mechanical Engineering, Koneru Lakshmaiah Education \\ Foundation, Vaddeswaram, Guntur, Andhra Pradesh, India \\ ${ }^{3}$ Professor, Department of Mechanical Engineering, Koneru Lakshmaiah Education Foundation, \\ Vaddeswaram, Guntur, Andhra Pradesh, India
}

\begin{abstract}
In the present work Copper $(\mathrm{Cu})$ is used as a dopant element in titanium dioxide $\left(\mathrm{TiO}_{2}\right)$ crystal structure to enhance the photovoltaic performance of the silicon (Si) solar cells fabricated with $\mathrm{TiO}_{2}$ thin film. Highly ordered Copper doped $\mathrm{TiO}_{2}$ particles were synthesized by using hydrothermal method with different molar concentrations of 0.25 , $0.5,0.75$, and $1.0 \%$ and by dispersing in $5 \mathrm{ml}$ of ethanol. During this process Copper doped $\mathrm{TiO}_{2}$ layers were coated on mesoporous $\mathrm{TiO}_{2}$ films by spin coating process. The effect of $\mathrm{Cu}$ doping concentration on the photovoltaic performance of Si solar cell has been investigated. It is observed that power conversion efficiency of the Cu doped solar cells increased from $6.61 \%$ at $0.25 \%$ molar concentration to $8.86 \%$ at $0.5 \%$ molar concentration. Further it is observed that improvement in power conversion efficiency of the solar cells is superior with $\mathrm{Cu}$ doped $\mathrm{TiO}_{2}$ when compared with the solar cells doped with other elements viz., $\mathrm{Zn,Fe,Eu,Al.}$

KEYWORDS: Si solar Cell, $\mathrm{TiO}_{2}$ Thin Film, Cu Doping \& Efficiency
\end{abstract}

Received: May 28, 2018; Accepted: Jun 18, 2018; Published: Jul 06, 2018; Paper Id.: IJMPERDAUG201834

\section{NOMENCLATURE}

- I Current

- V Voltage

- $\mathbf{V}_{\text {oc }}$ Open Circuit Voltage

- $\mathbf{I}_{\mathrm{sc}}$ Short Circuit current

- $\boldsymbol{\eta}$ Efficiency

- PV Photovoltaic

- UV Ultra Violet 


\section{INTRODUCTION}

Solar cells or photovoltaic (PV) systems which provide clean electricity from sunlight have attracted a lot of attention due to their ability, reliability, and accessibility. The performance of solar cell can be improved or enhanced by coating with subwavelength semi-conductor nano-structures which brings in reduced reflection losses and better light manipulation and/or trapping at sub-wavelength scale [1]. PV cells are composed of layers of semiconductor materials, conventionally silicon in its different crystalline forms, i. e. mono- or multi-crystalline. While the crystallized silicon does not show promising electric conducting behavior, selectively contaminating the semiconductor at a controlled level, namely doping, helps to generate a good amount of electric current [2, 3]. Thus for achieving best efficiency, it is necessary to design solar cells with specific geometries to benefit from some interesting characteristics, e.g., using metallic and semiconductor nano-structures which can cause extraordinary optical transmission for light localization [4-6]. Though semiconductor nanostructures improve light absorption performance [7-10] the solar cells need to be designed properly taking into account larger surface to volume ratio provided for sunlight exposure on the PV cell surface once covered with nano-structures [11]. Silicon solar cells, coated with dielectric interfaces like $\mathrm{Cu}$ doped $\mathrm{TiO}_{2}$ can increase their efficiency compared with cells coated with other elements.

Al-doped $\mathrm{TiO}_{2}$ layers are generally coated on the mesoporous $\mathrm{TiO}_{2}$ films by a chemical bath deposition process, followed by sintering at $500^{\circ} \mathrm{C}$. These cells exhibit an improvement in two aspects enhancing the electron transport and suppressing the charge recombination process. The power conversion efficiency of $\mathrm{Al}$-doped $\mathrm{TiO}_{2}$ cell is superior than mesoporous $\mathrm{TiO}_{2}$ coated cell [12]. Similarly, many authors have reported an improvement in solar cell efficiency by overcoating on solar cells with $\mathrm{Co}, \mathrm{Cd}, \mathrm{Fe}, \mathrm{Zn}, \mathrm{Gd}$, Eu doped $\mathrm{TiO}_{2}$ thin films with different doping concentrations [13-18]. Co-doped with $\mathrm{TiO}_{2}$ generates maximum efficiency of 5.66\% [13]. Cd-doped with $\mathrm{TiO}_{2}$ generates maximum efficiency of $3.06 \%$ [14]. Fe doped with $\mathrm{TiO}_{2}$ generates maximum efficiency of $2.78 \%$ [15]. Zn doped with $\mathrm{TiO}_{2}$ generates maximum efficiency of $6.58 \%$ [16]. Gd-doped $\mathrm{TiO}_{2}$ generates maximum efficiency of $1.18 \%$ [17] and Eu doped with $\mathrm{TiO}_{2}$ different concentrations gives maximum efficiency of $2.47 \%$ [18].

To the best of author's knowledge, till now no reports were found with $\mathrm{Cu}$ doped $\mathrm{TiO}_{2}$. Most of the time authors have concentrated on surface modification with copper for applications such as photocatalytic etc. [19-23]. Thus the present paper is aimed at analyzing the characteristics of a single crystalline $\mathrm{Si}$ solar cell coated with copper doped $\mathrm{TiO}_{2}$. The variation in efficiency \& I-V characteristics is compared with the performance of cells doped with other material and found that $\mathrm{Cu}$ doped $\mathrm{TiO}_{2}$ is superior to cells with other doping materials.

\section{EXPERIMENTAL}

With the impregnation method, copper doped mesoporous $\mathrm{TiO}_{2}$ particles were obtained by mixing the assynthesized particles into a beaker containing an aqueous solution of $\mathrm{CuCl}_{2} \cdot 2 \mathrm{H}_{2} \mathrm{O}$ with a copper concentration of 0.25 , $0.5,0.75$ and $1 \%$. The mixture is stirred well for 1 -hour maintaining at $\sim 70^{\circ} \mathrm{C}$ after cooling, the sample is washed with deionized water and filtered. It is dried in a hot air oven for 6 hours at $100{ }^{0} \mathrm{C}$ to get $\mathrm{Cu}$ doped mesoporous $\mathrm{TiO}_{2}$, which is pale brown in colour.

Different concentration solutions for coating were prepared by dispersing the known amount of Copper modified $\mathrm{TiO}_{2}$ in $5 \mathrm{ml}$ of ethanol. These solutions were coated on single crystalline Si solar cells with the assistance of a spin coating unit of VB Ceramics at a high speed of typically around $500 \mathrm{rpm}$ for $40 \mathrm{sec}$ followed by annealing at $450^{\circ} \mathrm{C}$ for 1 -hour in 
order to evaporate ethanol. Open circuit voltage $\left(V_{o c}\right)$, short circuit current $\left(\mathrm{I}_{\mathrm{sc}}\right)$ for coated cells were analysed using solar module analyser of MECO (model no. 9009). An experimental setup was designed and framed to measure the above parameters. An incandescent light was placed in such way that the distance from light to the test bed is fixed. The intensity of the incident light is evaluated with the help of lux meter (MASTECH; Model No: MS6610).

\section{UV-Vis Analysis of $\mathrm{TiO}_{2}$ and $\mathrm{Cu}$ Doped $\mathrm{TiO}_{2}$}

Mesoporous $\mathrm{TiO}_{2}$ and $\mathrm{Cu}$ doped $\mathrm{TiO}_{2}$ at different concentrations were characterized using UV-Vis spectrophotometer (Lab India) as shown in fig 1(a) and 1(b). Band gap energy values are calculated by representing the reflectance.

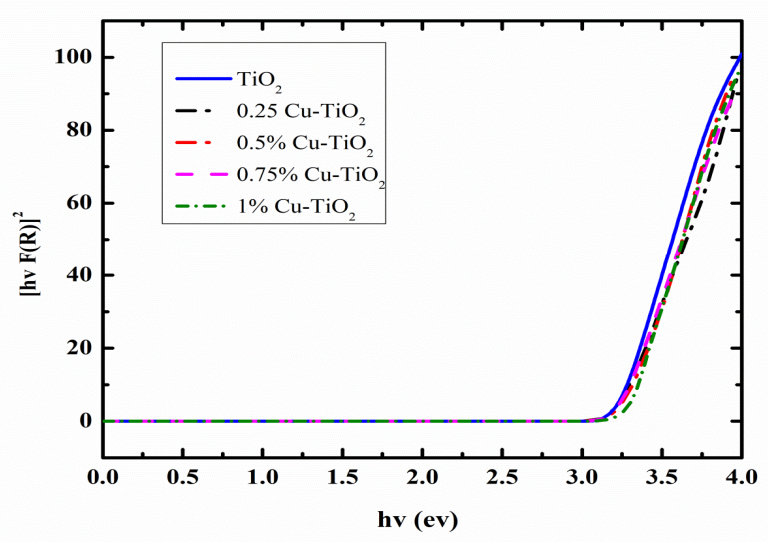

Figure 1(a): Band Gap Curves of Mesoporous $\mathrm{TiO}_{2}$ and $\mathrm{Cu}$ Doped $\mathrm{TiO}_{2}$ at $100{ }^{\circ} \mathrm{C}$ at Different Concentrations

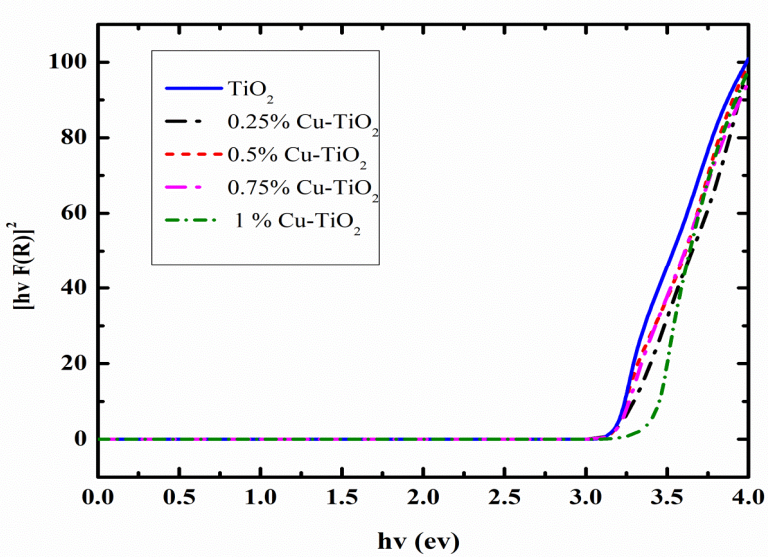

Figure 1(b): Band Gap Curves of Mesoporous $\mathrm{TiO}_{2}$ and $\mathrm{Cu}$ Doped $\mathrm{TiO}_{2}$ at $120{ }^{\circ} \mathrm{C}$ Different Concentrations

Figure 1(a) and figure 1(b) reveals that the band gap curves of mesoporous $\mathrm{TiO}_{2}$ and $\mathrm{Cu}$ doped $\mathrm{TiO}_{2}$ at two different temperatures, i. e. $100^{\circ} \mathrm{C}$ and $120^{\circ} \mathrm{C}$. The values are obtained by inducing the tangent to the intersection of hv (horizontal axis). It is observed that there is a slight increment in the band gap values at every particular increase in the molar concentration of $\mathrm{Cu}$ doped $\mathrm{TiO}_{2}$ cells table(1). When compared with a mesoporous $\mathrm{TiO}_{2}$ solar cell the band gap values of $\mathrm{Cu}$ doped $\mathrm{TiO}_{2}$ solar cells are superior. 
Table 1: Band Gap Values of $\mathrm{TiO}_{2}$ and $\mathrm{Cu}-$ Modified $\mathrm{TiO}_{2}$ Synthesized at Different Process Temperatures

\begin{tabular}{|c|c|c|}
\hline $\begin{array}{c}\text { Molar Concentration } \\
\text { of } \mathbf{C u}-\mathbf{T i O}_{\mathbf{2}}(\boldsymbol{\%})\end{array}$ & $\mathbf{C u}-\mathbf{T i O}_{\mathbf{2}}$ at Different Process Temperatures \\
\cline { 2 - 3 } & $\mathbf{1 0 0}{ }^{\mathbf{0}} \mathbf{C}$ & $\mathbf{1 2 0} \mathbf{C}$ \\
\hline 0 & 3.19 & 3.26 \\
\hline 0.25 & 3.21 & 3.29 \\
\hline 0.5 & 3.22 & 3.32 \\
\hline 0.75 & 3.27 & 3.38 \\
\hline 1.0 & 3.33 & 3.43 \\
\hline
\end{tabular}

Due to shifting of electrons from lower energy d-orbital to higher energy d-orbital in copper, strong absorption is observed at 700-800nm [25]. The absorption edge slightly shifts to the visible region for $\mathrm{Cu}$ doped $\mathrm{TiO}_{2}$ when compared to pure mesoporous $\mathrm{TiO}_{2}$. Hence it can be inferred that modifying $\mathrm{TiO}_{2}$ with copper increases the light absorption capacity of mesoporous $\mathrm{TiO}_{2}$ with visible-light response.

\section{RESULTS AND DISCUSSIONS}

In order to enhance the transport properties of the $\mathrm{TiO}_{2}$ layer doping with metal ions, the method is explained in experimental. $\mathrm{Cu}$ was used as a dopant material in this study and the power conversion efficiency at different molar concentrations is studied and compared with other doping elements. As a result of doping of $\mathrm{Cu}$ in $\mathrm{TiO}_{2}$ layers, there is an increase in the photo-catalytic activity [24]. This increase in photo-catalytic activity leads to increase in power conversion efficiency of the $\mathrm{Cu}$ doped $\mathrm{TiO}_{2} \mathrm{Si}$ solar cell.

To investigate the influence of surface modification on the photo- voltaic properties of Si solar cell the short circuit current $\left(\mathrm{I}_{\mathrm{sc}}\right)$, open circuit voltage $\left(\mathrm{V}_{\mathrm{oc}}\right)$ characteristics are shown in figure (2) and table (2). Compared with the other molar concentration cells $0.5 \% \mathrm{Cu}$ doped $\mathrm{TiO}_{2}$ cell yields high open circuit voltage $\left(\mathrm{V}_{\mathrm{oc}}\right)$ of $0.52 \mathrm{~V}$ and short-circuit current $\left(\mathrm{I}_{\mathrm{sc}}\right)$ of $134 \mathrm{~mA}$ from the table (2).

\section{Table 2: Open Circuit Voltage $\left(V_{\text {oc }}\right)$, Short Circuit Current $\left(I_{\text {sc }}\right)$ and Efficiency ( $\eta$ ) of Different Molar Concentrations of $\mathrm{Cu}$ Doped $\mathrm{TiO}_{2}$ Coated on $\mathrm{TiO}_{2}$ Layered Solar Cells}

\begin{tabular}{|c|c|c|c|}
\hline $\begin{array}{c}\text { Molar Concentration } \\
\text { of } \mathbf{C u}-\mathbf{T i O}_{\mathbf{2}}(\mathbf{\%})\end{array}$ & $\begin{array}{c}\text { Voltage } \\
\left(\mathbf{V}_{\mathbf{O C}}\right)(\mathbf{V})\end{array}$ & $\begin{array}{c}\text { Current } \\
\left(\mathbf{I}_{\mathbf{S C}}\right)(\mathbf{m A})\end{array}$ & $\begin{array}{c}\text { Efficiency } \\
(\boldsymbol{\eta})(\boldsymbol{\%})\end{array}$ \\
\hline 0.25 & 0.51 & 78 & 6.21 \\
\hline 0.5 & 0.52 & 134 & 8.86 \\
\hline 0.75 & 0.52 & 93 & 6.68 \\
\hline 1.0 & 0.41 & 72 & 3.73 \\
\hline
\end{tabular}

Table 2 depicts that for $0.5 \%$ molar concentration of $\mathrm{Cu}$ doped $\mathrm{TiO}_{2}$ the efficiency value is $8.86 \%$. The increase in power conversion efficiency at this concentration can be attributed to decrease in electron-hole recombination and enhance charge separation which in turn increases the efficiency of the solar cell. It is evident that as in the table (2) the concentration increases power conversion efficiency up to certain level and starts decreasing. 


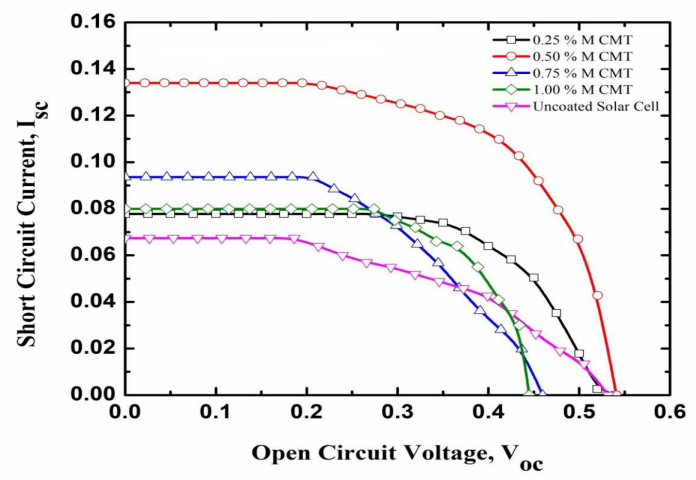

Figure 2: I-V Curves of Different Concentrations of $\mathrm{Cu}$ Doped $\mathrm{TiO}_{2}$

Figure 2 reveals I-V curves of $\mathrm{Cu}$ doped $\mathrm{TiO}_{2}$ with different molar concentrations $(0.25$ to $1.0 \%)$. It is observed from the figure that the short circuit current $\left(\mathrm{I}_{\mathrm{sc}}\right)$ is $134 \mathrm{~mA}$ and open circuit voltage $\left(\mathrm{V}_{\mathrm{oc}}\right)$ of $0.52 \mathrm{~V}$ is produced for $0.5 \%$ $\mathrm{Cu}$ doped $\mathrm{TiO}_{2}$ cell from the table (2). When the concentration of doping increases there is the decrease in the production of short circuit current $\left(\mathrm{I}_{\mathrm{sc}}\right)$ and open circuit voltage $\left(\mathrm{V}_{\mathrm{oc}}\right)$. Finally $\mathrm{Si}$ solar cell with $0.5 \% \mathrm{Cu}$ doped $\mathrm{TiO}_{2}$ gives high $\mathrm{I}_{\mathrm{sc}}$, and $\mathrm{V}_{\mathrm{oc}}$ values than cells with other concentrations.

Table 3: Comparison of Power Conversion Efficiencies of Different Elements Doped with $\mathrm{TiO}_{2}[13-18]$.

\begin{tabular}{|l|c|c|}
\hline $\begin{array}{c}\text { Element Doped } \\
\text { with } \mathbf{T i O}_{\mathbf{2}}\end{array}$ & $\begin{array}{c}\text { Molar Concentration } \\
(\boldsymbol{\%})\end{array}$ & $\begin{array}{c}\text { Highest Efficiency } \\
(\boldsymbol{\eta})(\boldsymbol{\%})\end{array}$ \\
\hline Carbon monoxide $(\mathrm{CO})$ & 2 & 5.66 \\
\hline Cadmium $(\mathrm{Cd})$ & 2 & 3.06 \\
\hline Iron $(\mathrm{Fe})$ & 1 & 2.78 \\
\hline Zinc $(\mathrm{Zn})$ & 0.5 & 6.58 \\
\hline Europium $(\mathrm{Eu})$ & 5 & 2.47 \\
\hline Copper $(\mathrm{Cu})$ & 0.5 & 8.86 \\
\hline
\end{tabular}

Table 3 presents the comparison of power conversion efficiencies of different elements doped with $\mathrm{TiO}_{2}$. Here $0.5 \%$ molar concentration of $\mathrm{Cu}$ doped $\mathrm{TiO}_{2}$ cells gives more efficiency than the other elements of higher concentration doping with $\mathrm{TiO}_{2}$. Cu effectively increased the short-circuit current $\left(\mathrm{I}_{\mathrm{sc}}\right)$ and power conversion efficiency. It is evident from the present data that $\mathrm{Cu}$ doped $\mathrm{TiO}_{2}$ generates higher power conversion efficiency than other elements.

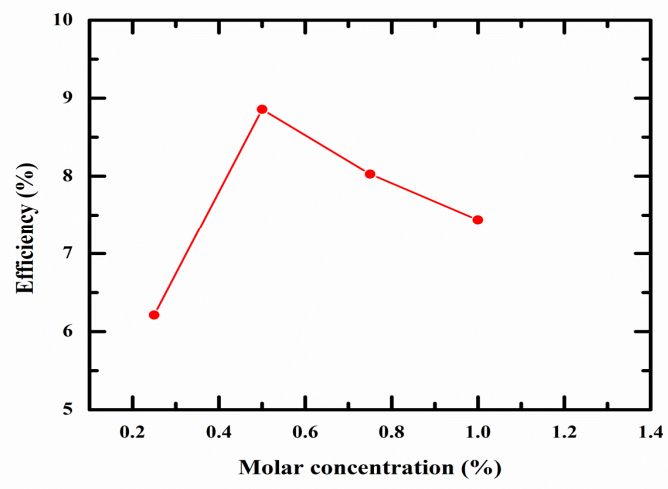

Figure 3: Efficiency Curve of $\mathrm{Cu}$ Doped $\mathrm{TiO}_{2}$ at Different Molar Concentrations 
Figure 3 reveals the efficiency of $\mathrm{Cu}$ doped $\mathrm{TiO}_{2}$ at different molar concentrations. Si solar cell obtained high power conversion efficiency at $0.5 \%$ molar concentration and gradually decreases as the molar concentration of Cu doped $\mathrm{TiO}_{2}$ increases.

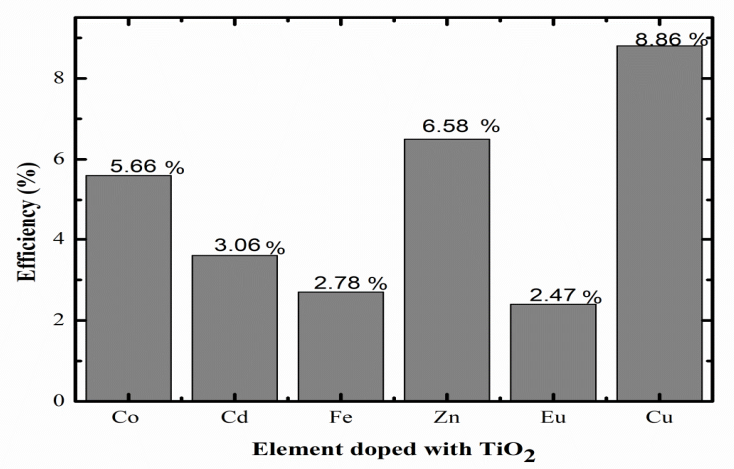

Figure 4: Comparison of Power Conversion Efficiencies of Different Elements Doped with $\mathrm{TiO}_{2}$ [13-18].

Figure 4 reveals the comparison of power conversion efficiencies of different elements doped with $\mathrm{TiO}_{2}$. $\mathrm{The}$ power conversion efficiencies of doping elements viz., $\mathrm{Co}, \mathrm{Cd}, \mathrm{Fe}, \mathrm{Zn}$, and Eu are low when compared with $\mathrm{Cu}$.

\section{CONCLUSIONS}

Quantitative and valuable optimization for fabrication of $\mathrm{Si}$ solar cells with $\mathrm{Cu}$ doped $\mathrm{TiO}_{2}$ thin films is taken up in this work. $\mathrm{TiO}_{2}$ thin films doped with $\mathrm{Cu}$ at different concentrations were successfully produced on $\mathrm{Si}$ solar cells and tested. Effect of $\mathrm{Cu}$ doping on Si solar cells, short circuit current $\left(\mathrm{I}_{\mathrm{sc}}\right)$ generated and power conversion efficiency were estimated. The power conversion efficiency of $\mathrm{Cu}$ doped $\mathrm{TiO}_{2}$ is found increasing with increase in the concentration of copper, reached a maximum and starts decreasing. The optimal concentration where the efficiency is maximum was found to be at $0.5 \%$ concentration. Further on comparison with data available in the literature for other doped materials like Fe, $\mathrm{Eu}, \mathrm{Zn}, \mathrm{CO}$ etc., it is inferred that $\mathrm{Cu}$ doped $\mathrm{TiO}_{2}$ has a max conversion efficiency of $8.86 \%$.

\section{ACKNOWLEDGEMENTS}

The Authors would like to thank the Management and Director, Centre for Advanced Energy Studies for their support.

\section{REFERENCES}

1. S. Patil et al. (2013), Passivation of n-type emitter and p-type base in solar cells via oxygen terminated silicon nanoparticles, Prog. Photovolt: Res. Appl. 21, 1146.

2. Wahab et al. (2012), Optimum doping for $n+p$ silicon solar cell and the J-V characteristic. In Proceedings of the 2012 International Conference on Enabling Science and Nanotechnology (ESciNano), Johor Bahru, Malaysia,

3. Yang et al. (2010), Germanium-doped crystal silicon for solar cells. In Proceedings of the 2010 10th IEEE International Conference on Solid-State and Integrated Circuit Technology (ICSICT), Shanghai, China, 1-4.

4. Ebbesen et al. (1998), Extraordinary optical transmission through sub-wavelength whole arrays. Nature, 391, 667-668.

5. Søndergaard. (2010), Extraordinary Optical Transmission Enhanced by Nano focusing. Nano Lett., 10, 3123-3128. 
6. Duhring et al. (2013) Optimization of extraordinary optical absorption in plasmonic and dielectric structures. J. Opt. Soc. Am. $B, 30,1154-1160$

7. M. B. Rajendra Prasad et al. (2013).Employing green synthesized silver nanoparticles as light harvesters in nanostructured solar cells, J. Renew. Sustain. Energy 5, 031615.

8. Tsakalakos et al (2007) J. Silicon nanowire solar cells. Appl. Phys. Lett., 91.

9. Zhu et al. (2009), Optical Absorption Enhancement in Amorphous Silicon Nanowire and Nano cone Arrays. Nano Lett. 9, 279-282.

10. Cao et al. (2010), Semiconductor Nanowire Optical Antenna Solar Absorbers. Nano Lett., 10, 439-445.

11. Beard et al. (2014), The promise and challenge of nanostructured solar cells. Nano technology. 9, 951-954.

12. Ran Li et al. (2018), Enhancement of power conversion efficiency of dye sensitized solar cells by modifying mesoporous $\mathrm{TiO}_{2}$ photoanode with Al-doped $\mathrm{TiO}_{2}$ layer. Journal of Photochemistry and Photobiology A: Chemistry.

13. M.I. Khan et al. (2018) Synthesis, characterization and application of Co doped $\mathrm{TiO}_{2}$ multilayer thin films. Results in Physics, S2211-379730253-5.

14. A. Ranjitha et al. (2014). Inverted organic solar cells based on $\mathrm{Cd}$-doped $\mathrm{TiO}_{2}$ as an electron extraction layer. Super lattices and Microstructures, 74-114-122.

15. Hussein, Mustafa Ma, and Manal M. Abdullah. "IV Characteristics of CDTE/PTNPS/AL2O3/PTNPS/SI Thin Film Solar Cell."

16. Arif Koseman et al. (2016), Fe doped $\mathrm{TiO}_{2}$ thin film as electron selective layer for inverted solar cells. Solar Energy, 132-511517.

17. A.H. Ghanbari Niaki et al. (2014), Double-layer dye-sensitized solar cells based on Zn-doped TiO2 transparent and light scattering layers: Improving electron injection and light scattering effect, Solar Energy, 103-210-222.

18. A. Ranjitha et al, (2013). CdS quantum dot sensitized nanocrystalline Gd-doped TiO2 thin films for photo electrochemical solar cells, J Mater Sci: Mater Electron24:3014-3020.

19. Osman Ornek et al. (2017), Performance enhancement of inverted type organic solar cells by using Eu doped TiO $\mathrm{O}_{2}$ thin film, Surfaces Interfaces, S2468-0230-30091-3.

20. Yue-hua X et al. (2008), Preparation and characterization of $\mathrm{Cu}_{2} \mathrm{O}-\mathrm{TiO} \mathrm{O}_{2}$, Efficient photocatalytic degradation of methylene blue, Materials Research Bulletin 43 (3474-3482).

21. Gonghu Li et al. (2008), Role of Surface/Interfacial $\mathrm{Cu}^{2+}$ Sites in the Photocatalytic Activity of Coupled CuO-TiO Nanocomposites, J. Phys. Chem. C, 112, 19040-19044.

22. Jeffrey C et al, (2009), Photocatalytic Reduction of Greenhouse Gas $\mathrm{CO}_{2}$ to Fuel: Catal Surv Asia 13:30-40.

23. Kumar Ajay R et al, (2018), Electrochemical Studies of Mesoporous and Copper modified Mesoporous TiO - Anode Material: The European Physical Journal Plus 133, 179.

24. Mohammad Reza Delsouz, Khaki et al, (2017), Evaluating the efficiency of nano-sized Cu doped TiO ${ }_{2} / \mathrm{ZnO}$ photocatalyst under visible light irradiation Journal of Molecular Liquids, S0167-732233370-6.

25. Hamzah, A. M. "Antibacterial of Cassia acutifoliaextract against some bacteria and anti-biofilm formation activities against Pseudomonas aeruginosa." Int. J. of Humanities, Arts, Med. and Sci 4.9 (2016): 2454-4728. 
26. $R$ Ajay Kumar et al. (2018), Mesoporous $\mathrm{TiO}_{2}$ and Copper-modified $\mathrm{TiO}_{2}$ nanoparticles: A Case study, The European Physical Journal Plus, 133- 60.

27. Sami Ratmi et al. (2017), Indoor Light Enhanced Photocatalytic Ultra-Thin Films on Flexible Non-Heat Resistant Substrates Reducing Bacterial Infection Risks. Catalysts 7, 57. 